\title{
Mapping psychosocial interventions in familial colorectal cancer: a rapid systematic review
}

Andrada Ciucă', Ramona Moldovan ${ }^{1,2,3^{*}}$ and Adriana Băban ${ }^{1}$

\begin{abstract}
Background: Approximately 5\% of colorectal cancer (CRC) cases are part of a well-defined inherited genetic syndrome and up to approximately $30 \%$ of these cases have a clinically defined familial basis. Psychosocial interventions in familial colorectal cancer address aspects mainly focused on affective, cognitive and behavioural outcomes. The present review aims to systematically map out the available psychosocial interventions for individuals with a family history of CRC and describe the current state of the research.

Methods: An extensive electronic search was conducted to investigate the literature published until June 2020. Inclusion criteria consisted of quantitative studies published in English that explored the impact of psychosocial interventions for familial CRC, clearly defined the psychosocial intervention offered and included participants with a family history of CRC.

Results: The analysis included 52 articles. Genetic counselling, educational interventions, psychological interventions and multimodal interventions were identified across the studies. In terms of diagnoses, Lynch Syndrome, Familial Adenomatous Polyposis, Familial Colorectal Cancer were the main conditions included in the studies. Affective, cognitive, behavioural aspects and quality of life emerged as the most frequently explored outcomes. The studies included individuals with both personal and familial history of CRC or family history alone.

Conclusions: Our rapid review provides an overview of the literature exploring the impact of psychosocial interventions for familial CRC. The psychosocial interventions identified had an overwhelmingly positive impact across all types of outcomes measured. Genetic counselling appeared to be most beneficial, and this is expected as it is purposively designed to address genetic conditions. Further quantitative analysis of primary empirical research is needed to determine the efficacy and effectiveness of psychosocial interventions as well as the mechanisms through which they exert their effect.
\end{abstract}

Keywords: Psychosocial interventions, Genetic counselling, Familial colorectal cancer, Systematic review

\section{Introduction}

Colorectal cancer (CRC) is the third most frequent form of cancer and the third leading cause of cancer death [1]. A family history of CRC is known to be associated

\footnotetext{
*Correspondence: ramona.moldovan@manchester.ac.uk

${ }^{1}$ Department of Psychology, Babeş-Bolyai University, Cluj-Napoca, Romania

Full list of author information is available at the end of the article
}

with an increased risk of developing CRC [2]. Approximately $5 \%$ of CRC cases are part of a well-defined inherited genetic syndrome [3] such as Lynch Syndrome (LS) and Familial Adenomatous Polyposis (FAP). Also, up to approximately $30 \%$ of the total cases of CRC have a clinically defined familial basis [3] and, for the purpose of this review, are clustered under the familial colorectal cancer label (fCRC). 
Psychosocial interventions address various psychological and social aspects of a condition and can be delivered in a counselling format, as health education or with a focus on social support. In familial CRC, psychosocial interventions are usually focused on (1) affective outcomes such as distress, anxiety and depression in relation to cancer or genetic testing, (2) cognitive outcomes such as knowledge about cancer and genetics, risk perception, or decision making, (3) behavioural outcomes related to screening, surveillance, and genetic testing.

In the absence of a systematic review, it is difficult to distil the vast amount of publications looking at rather diverse psychosocial interventions targeting various psychological, familial or social aspects. The present study aims to systematically map out the available psychosocial interventions for individuals with a family history of CRC and the current state of the research, in order to identify possible gaps and discuss the potential impact of the interventions.

\section{Methods}

An extensive electronic search was conducted to investigate the literature published until June 2020. PubMed, PsycInfo, and Cochrane databases were searched using the following keywords: colon cancer, colorectal cancer, bowel cancer, psychological intervention, psychosocial intervention, counselling, genetic counselling, psychoeducation, psychotherapy. The complete search syntax is presented in Table 1. Reference lists of the articles from the full text assessment phase were manually searched to identify additional studies.

Inclusion criteria consisted of (1) quantitative studies published in English that (2) explored the impact of psychosocial interventions for familial CRC, (3) clearly defined the psychosocial intervention offered, and (4) included participants with a family history of CRC. Studies were coded to identify: authors, year of publication, intervention type (genetic counselling, educational intervention, psychological intervention), study design (prospective, experimental), diagnosis (Lynch Syndrome, Familial Adenomatous Polyposis, familial Colorectal Cancer), cancer history (familial, personal), outcome types (affective, behavioural, cognitive, quality of life), providers' background (genetic counsellor, medical genetics background, non-genetics medical background), intervention format (face-to-face, written, telephone), sample size and mean age of the participants. Two authors independently assessed the studies and extracted the relevant data.

\section{Results}

The literature search yielded 2702 articles. Based on the inclusion criteria, 59 publications were eligible for analysis. Of these, 7 were excluded due to multiple publications from the same cohort [4-10] (e.g. follow-up studies were available and data was more robust in the most recently published article or articles included secondary analyses). The quantitative analysis included 52 articles. Figure 1 shows the literature search flow diagram. The total number of participants included in the studies was 8643; of these, several participants are duplicates due to studies recruiting individuals from the same cohort but provided different interventions and/or measured different outcomes. Table 2. presents the coding and characteristics of the articles included in the review.

\section{Overview of findings}

Three main types of psychosocial interventions were identified: genetic counselling, educational interventions, psychological interventions; for the purpose of this review, we categorised the various combinations of genetic counselling, educational, and psychological interventions as multimodal interventions. Figure 2a. presents the scaled Venn diagram of the interventions and their intersection represents the multimodal interventions. In terms of explored outcomes, we identified a wide range of affective, cognitive and behavioural outcomes either as a unique, stand-alone measure or in different combinations. Quality of life was one of the explored outcomes, but only in combinations with others. Figure 2b. shows the scaled Venn diagram of the explored outcomes and the intersections represent the different combinations found in the studies. In terms of diagnoses, LS was found in 25 studies, FAP in 2 studies, fCRC in 20 studies and combinations of the three were found in 5 studies. Figure 2c. presents the scaled Venn diagram of the diagnoses and the intersections represent different combinations found in the studies. Individuals with a family history of CRC were included in 35 studies and individuals with both personal and familial history of CRC were included

\section{Table 1 Search syntax}

(((()(((()(((()((colon cancer and psychological intervention)) OR (colon cancer and psychosocial intervention)) OR (colon cancer and psychotherapy)) OR (colon cancer and psychoeducational intervention)) OR (colon cancer and counseling)) OR (colon cancer and counselling)) OR (colorectal cancer and psychological intervention)) OR (colorectal cancer and psychosocial intervention)) OR (colorectal cancer and psychotherapy)) OR (colorectal cancer and psychoeducational intervention)) OR (colorectal cancer and counseling)) OR (colorectal cancer and counselling)) OR (bowel cancer and psychological intervention)) OR (bowel cancer and psychosocial intervention)) OR (bowel cancer and psychotherapy)) OR (bowel cancer and psychoeducational intervention)) OR (bowel cancer and counseling)) OR (bowel cancer and counselling) 


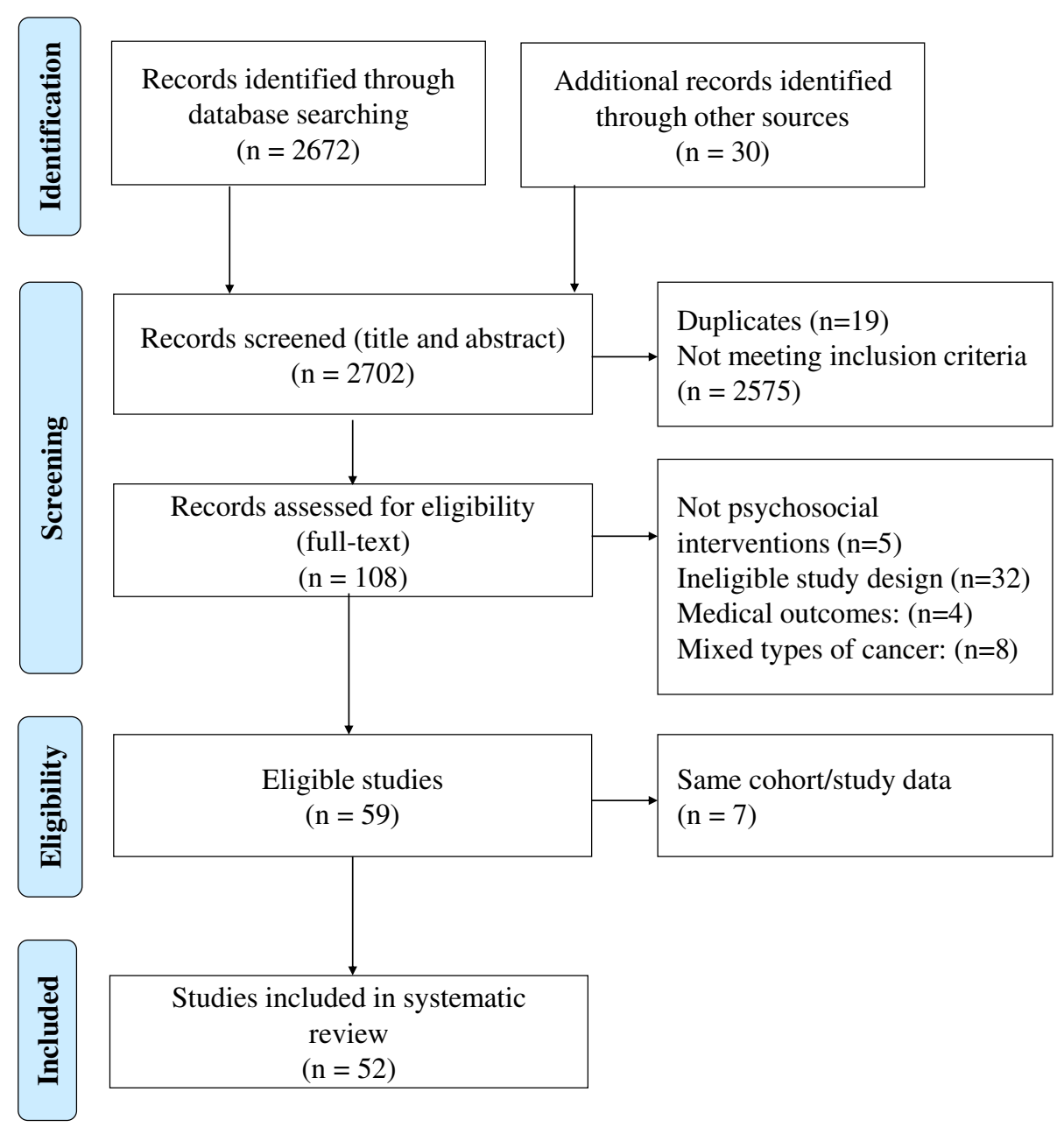

Fig. 1 Flow diagram

in 17 studies. Figure 2d. presents the scaled Venn diagram of individuals included in the studies based on their familial and personal history of CRC.

\section{Genetic counselling}

Genetic counselling is the process of "helping people understand and adapt to the medical, psychological and familial implications of genetic contributions to disease. This process integrates the following: (1) interpretation of family and medical histories to assess the chance of disease occurrence or recurrence; (2) education about inheritance, testing, management, prevention, resources and research; (3) counselling to promote informed choices and adaptation to the risk or condition" [63]. Genetic counselling was investigated in 23 studies, almost half of the articles included in this review. In 15 studies, it was offered to unaffected family members at risk for $\mathrm{CRC}$, and in 8 studies to individuals with a personal history of CRC. Affective outcomes (e.g. anxiety, depression, emotional distress, and specific fears) were investigated in 17 studies and they represent the most frequently explored outcome. Several studies [12, 27] reported an increase of the emotional distress immediately after a genetic test disclosure session; at follow up the reported scores tended to decrease back to baseline. Cognitive outcomes (e.g. knowledge about CRC and genetics, and perception of risk) were assessed in 12 studies. Behavioural outcomes (e.g. uptake of colonoscopy and gynaecological cancer screening) were addressed in 7 studies and quality of life in 5 studies. Genetic counselling was reported to have a positive impact on screening adherence for the mutation carriers, but non-carriers appeared to comply less with the screening recommendations. Genetic counselling was provided by a genetic counsellor in 11 studies and by a medical professional with background in genetics in 8 studies. In all studies genetic counselling was done face to face and it was usually supplemented by letters after the session. All but one 


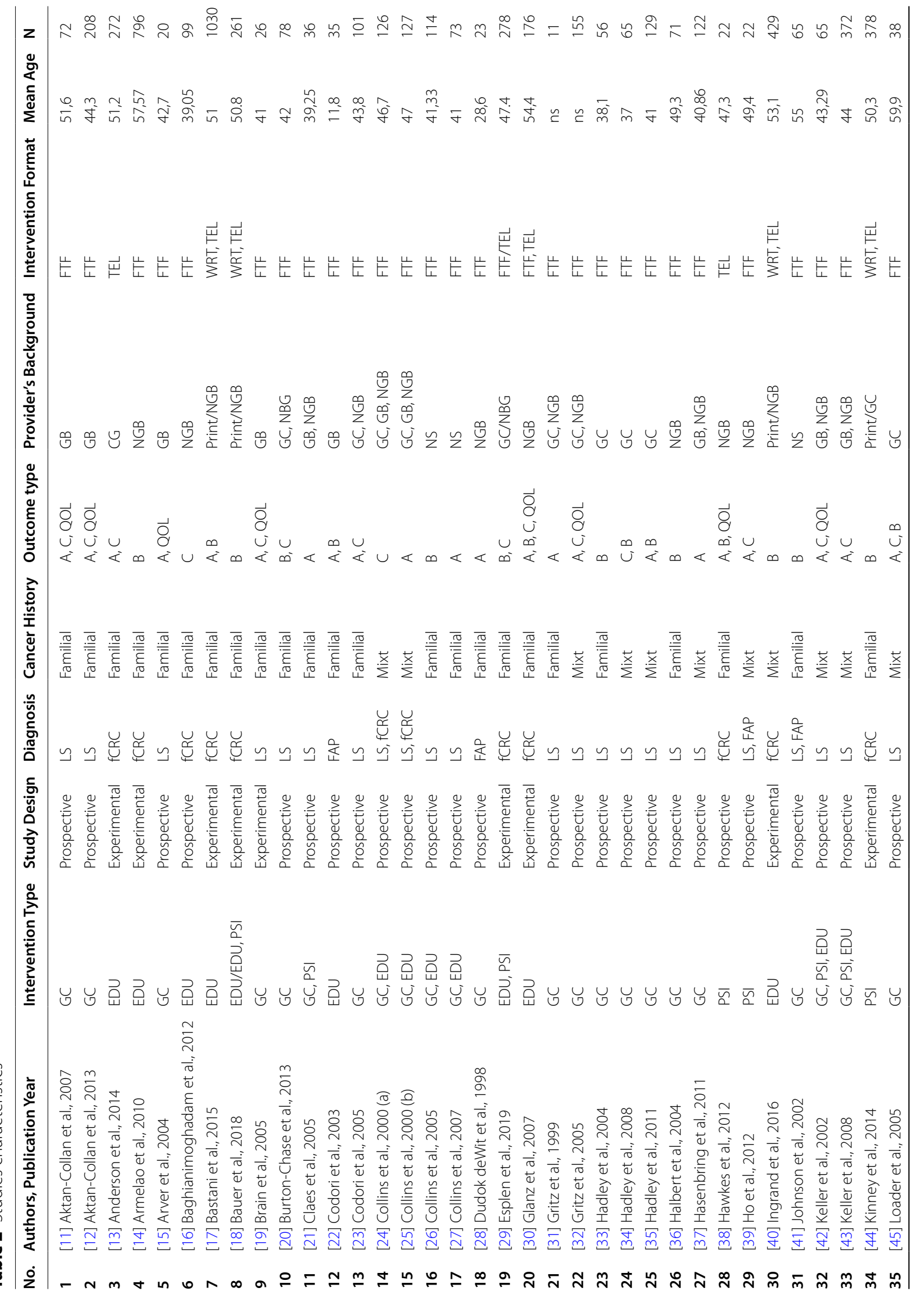




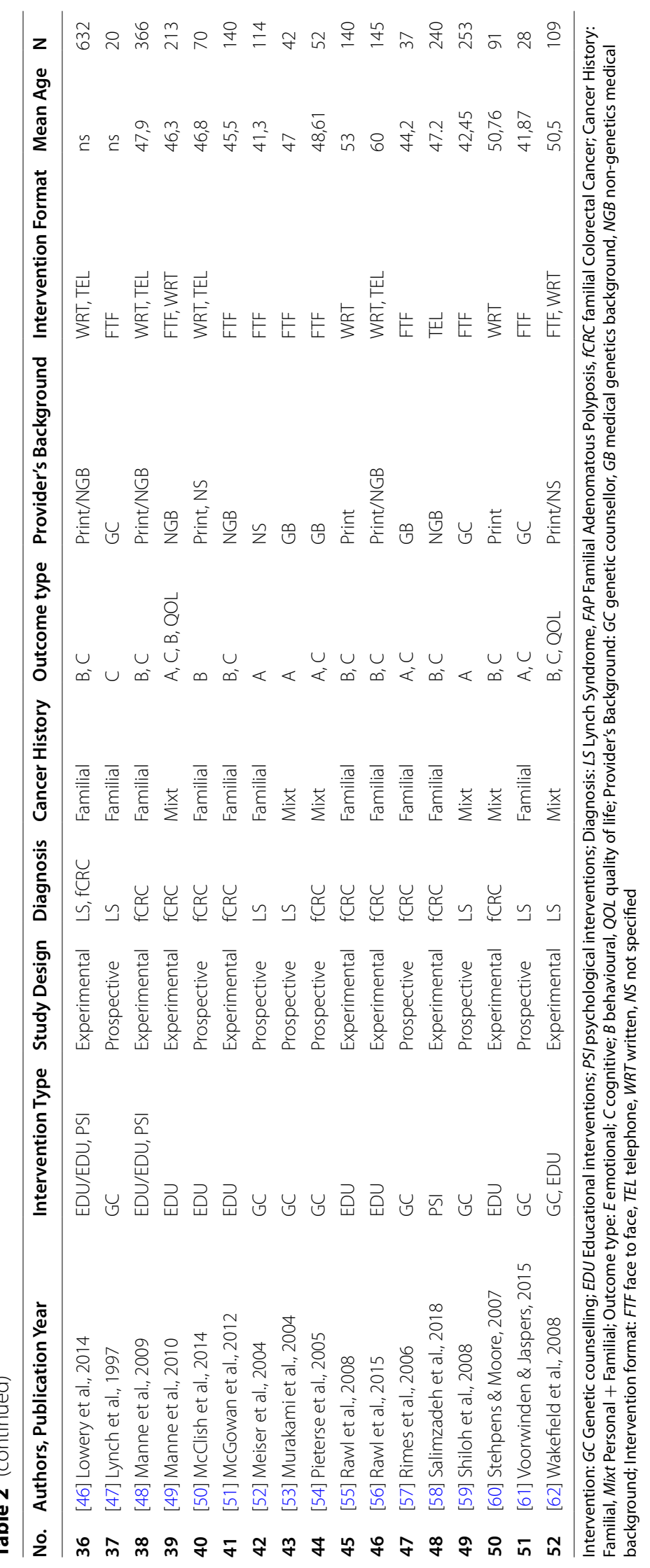




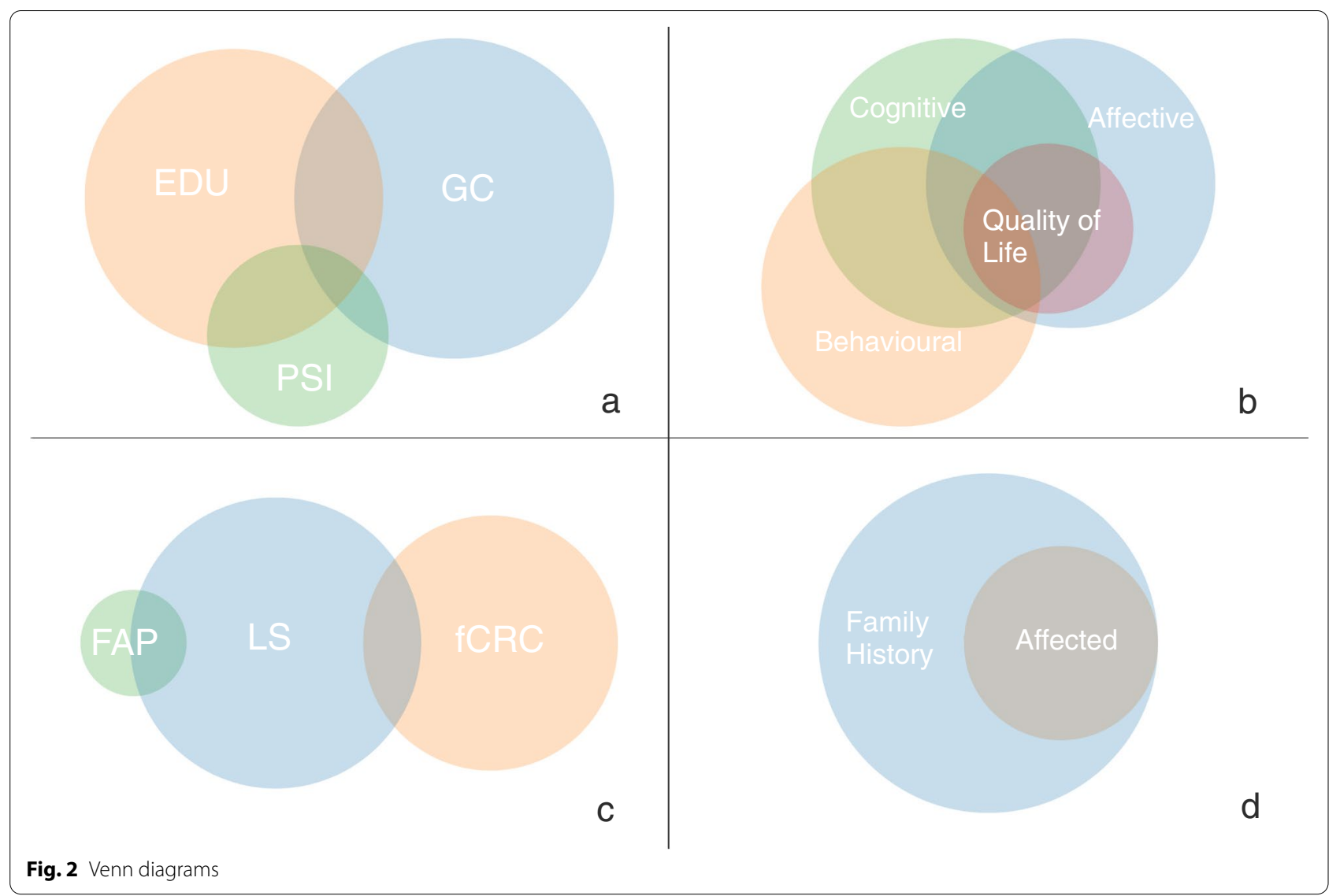

study measured the impact of genetic counselling with a prospective design (e.g., baseline and post intervention questionnaires, without a control group).

\section{Educational interventions}

Educational interventions in cancer setting are aimed at providing information to insure sufficient knowledge about the condition, prevention, management of symptoms. Educational interventions were found in 16 studies, approximately a third of the articles analysed and were mostly focused on providing knowledge about the risk of developing CRC and prevention strategies such as diet, physical activity and screening. In 13 studies, educational interventions were offered to individuals with a family history of CRC. The majority of the educational interventions were offered to individuals with a personal or a family history of fCRC. Behavioural outcomes (e.g. uptake of CRC screening, diet, physical activity) were measured in 12 studies and represent the most frequently investigated outcome. Cognitive outcomes (e.g., knowledge, perceived severity, attitudes towards CRC, screening intention) were explored in 6 studies. Affective outcomes (e.g. anxiety, specific fears, depression, optimism) were explored in 5 studies. Educational interventions were mostly provided by health professionals without a background in genetics (11 studies). The model of delivery was the most diverse across all psychosocial interventions, using written (i.e., booklets, leaflets, CDs), telephone, face to face, and mixed methods. All studies were strongly supportive of the important role education has on screening uptake and reported positive results. The impact of educational interventions on affective outcomes was found to be less prominent.

\section{Psychological interventions}

The psychological interventions found in the studies were based on various psychotherapy paradigms such as acceptance and commitment therapy or motivational interviews, and were aimed at supporting positive life changes, improving uptake of screening, or alleviating emotional distress. Psychological interventions were found in a small proportion of studies (4 studies) and targeted affective (e.g., anxiety, depression, hope), behavioural (e.g., uptake of colonoscopy, food consumption and physical activity) and cognitive outcomes (e.g., knowledge). Three studies included unaffected individuals at 
risk for fCRC and one study included individuals with a familial history of LS or FAP. The intervention was offered by health professionals with various professional backgrounds such as oncology nursing, clinical psychology, surgery in 3 studies and by a genetic counsellor in 1 study. Psychological interventions were provided by telephone in 3 studies and face to face in 1 study. All studies exploring psychological interventions reported a positive impact in alleviating emotional distress.

\section{Multimodal interventions}

Multimodal interventions consist of different combinations of the 3 main psychosocial interventions, and were explored in 12 studies. The outcomes investigated were varied, including affective outcomes in 5 studies, cognitive outcomes in 7 studies, behavioural outcomes in 6 studies and quality of life in 2 studies. Six studies included participants with a family history of CRC and 6 included participants with both family and personal CRC history. Multimodal interventions were provided face to face, by professionals with a wide variety of backgrounds. Three studies compared a multimodal intervention with educational intervention therefore these studies are included in both categories. All studies providing multimodal interventions predominantly reported positive impact across all types of outcomes measured.

\section{Discussions}

Our analysis provides an overview of the literature exploring the impact of psychosocial interventions for familial CRC. The analysis suggests that psychosocial interventions - genetic counselling, educational and psychological interventions - have an overall positive impact on emotional, cognitive, and behavioural outcomes. With an overview of the research available, we were also able to identify several research gaps and suggest potential strategies to address them.

Although psychosocial interventions generally reported a positive impact, it is essential for future research studies to rigorously assess their efficacy. Results from genetic counselling studies are undoubtedly positive: genetic counselling improves knowledge, emotional distress and screening adherence. In order to provide unequivocal empirical evidence supporting the efficacy of genetic counselling, it is essential for future research to encourage randomised clinical trials. Future research would also benefit from aligning in a more systematic manner the context and content of the interventions with the assessed outcomes. For instance, as hypothesised, educational interventions reported positive results on screening uptake. Yet, unsurprisingly, given the informative nature of the education interventions, their impact on affective outcomes was less prominent. This is in line with previous research in genetic counselling [64] and substantial empirical evidence from clinical psychology [65] showing that knowledge does not necessarily alleviate emotional distress. Undoubtedly, there is a clear need for more studies exploring the impact of psychological interventions for familial CRC. Psychological interventions have a strong empirical evidence base supporting their benefit in alleviating emotional distress for cancer in general [66], and various medical conditions [67], therefore only identifying 4 studies investigating psychological interventions was surprising. Although valuable in themselves, future research exploring multimodal interventions would also benefit from more clarity regarding the theory underlying the various psychosocial interventions, the expected mechanisms of change of the interventions offered and the specificity of the outcome measures used. That said, given the heterogeneity of the multimodal interventions, the rather modest impact reported was perhaps not surprising.

To conclude, the increased number of studies exploring psychosocial interventions for CRC and the positive impact reported was indeed encouraging. Mapping this research area also highlighted several limitations of the research in this field. The heterogeneity of the research designs, outcomes and measures used could benefit from a more programmatic approach. In order for psychosocial interventions to gather a critical mass of empirical evidence, to support their efficacy and clarify their mechanisms of change, robust research studies need to be designed and implemented.

\section{Acknowledgements \\ Not applicable.}

\section{Authors' contributions}

All authors contributed to the study conception and design. Literature search and analysis were performed by $A C, R M, A B$. The first draft of the manuscript was written by $A C$ and all authors commented on previous versions of the manuscript. All authors read and approved the final manuscript.

Funding

Not applicable.

Availability of data and materials

All data generated or analysed during this study are included in this published article and its supplementary information file.

\section{Declarations}

Ethics approval and consent to participate

Not applicable.

Consent for publication

Not applicable.

Competing interests

The authors declare that they have no competing interests. 


\section{Author details}

${ }^{1}$ Department of Psychology, Babeş-Bolyai University, Cluj-Napoca, Romania. ${ }^{2}$ Division of Evolution and Genomic Sciences, School of Biological Science, University of Manchester, Manchester, UK. ${ }^{3}$ Manchester Centre for Genomic Medicine, St Mary's Hospital, Manchester University Hospitals NHS Foundation Trust, Manchester, UK.

Received: 9 February 2021 Accepted: 12 October 2021

Published online: 03 January 2022

\section{References}

1. Siegel RL, Miller KD, Jemal A. Cancer statistics, 2020. CA Cancer J Clin. 2020;70(1):7-30 https://doi.org/10.3322/caac.21590.

2. Lowery JT, Ahnen DJ, Schroy PC, Hampel H, Baxter N, Boland CR, et al. Understanding the contribution of family history to colorectal cancer risk and its clinical implications: A state-of-the-science review. Cancer. 2016;122(17):2633-45 https://doi.org/10.1002/cncr.30080.

3. Jasperson KW, Tuohy TM, Neklason DW, Burt RW. Hereditary and familial Colon Cancer. Gastroenterology. 2010;138(6):2044-58 https://doi.org/10. 1053/j.gastro.2010.01.054

4. Aktan-Collan K, Haukkala A, Mecklin JP, Uutela A, Kääriäinen H. Comprehension of cancer risk one and 12 months after predictive genetic testing for hereditary non-polyposis colorectal cancer. J Med Genet. 2001;38(11):787-92. https://doi.org/10.1136/jmg.38.11.787.

5. Aktan-Collan K, Haukkala A, Mecklin JP, Uutela A, Kääriäinen H. Psychological consequences of predictive genetic testing for hereditary nonpolyposis colorectal cancer (HNPCC): A prospective follow-up study. Int J Cancer. 2001;93(4):608-11. https://doi.org/10.1002/ijc.1372.

6. Aktan-Collan K, Mecklin JP, Järvinen H, Nyström-Lahti M, Peltomäki P, Söderling I, et al. Predictive genetic testing for hereditary non-polyposis colorectal cancer: uptake and long-term satisfaction. Int J Cancer. 2000;89(1):44-50. https://doi.org/10.1002/(SICI)1097-0215(20000120)89:144:.:AID-IJC83.0.CO;2-3.

7. Claes E, Denayer L, Evers-Kiebooms G, Boogaerts A, Legius E. Predictive testing for hereditary non-polyposis colorectal cancer: motivation, illness representations and short-term psychological impact. Patient Educ Couns. 2004;55(2):265-74. https://doi.org/10.1016/j.pec.2003.11.002.

8. Codori AM, Petersen GM, Boyd PA, Brandt J, Giardiello FM. Genetic testing for cancer in children: short-term psychological effect. Archives of pediatrics \& adolescent medicine. 1996;150(11):1131-8. https://doi.org/ 10.1001/archpedi.1996.02170360021003.

9. Eliezer D, Hadley DW, Koehly LM. Exploring psychological responses to genetic testing for Lynch syndrome within the family context. PsychoOncology. 2014;23(11):1292-9. https://doi.org/10.1002/pon.3551.

10. Glenn BA, Herrmann AK, Crespi CM, Mojica CM, Chang LC, Maxwell AE, et al. Changes in risk perceptions in relation to self-reported colorectal cancer screening among first-degree relatives of colorectal cancer cases enrolled in a randomized trial. Health Psychol. 2011;30(4):481. https://doi. org/10.1037/a0024288.

11. Aktan-Collan K, Haukkala A, Pylvänäinen K, Järvinen HJ, Aaltonen LA, Peltomäki $P$, et al. Direct contact in inviting high-risk members of hereditary colon cancer families to genetic counselling and DNA testing. J Med Genet. 2007;44(11):732-8. https://doi.org/10.1136/jmg.2007.051581.

12. Aktan-Collan $K$, Kääriäinen $H$, Järvinen $H$, Peltomäki $P$, Pylvänäinen $K$, Mecklin JP, et al. Psychosocial consequences of predictive genetic testing for lynch syndrome and associations to surveillance behaviour in a 7-year follow-up study. Familial Cancer. 2013;12(4):639-46. https://doi.org/10. 1007/s10689-013-9628-9.

13. Anderson AE, Flores KG, Boonyasiriwat W, Gammon A, Kohlmann W, Birmingham WC, et al. Interest and informational preferences regarding genomic testing for modest increases in colorectal cancer risk. Public Health Genomics. 2014;17(1):48-60. https://doi.org/10.1159/000356567.

14. Armelao F, Orlandi PG, Tasini E, Franceschini G, Franch R, Paternolli C, et al. High uptake of colonoscopy in first-degree relatives of patients with colorectal cancer in a healthcare region: a population-based, prospective study. Endoscopy. 2010;42(01):15-21. https://doi.org/10.1055/s-0029-1215324.

15. Arver B, Haegermark A, Platten U, Lindblom A, Brandberg Y. Evaluation of psychosocial effects of pre-symptomatic testing for breast/ovarian and colon cancer pre-disposing genes: a 12-month follow-up. Familial Cancer. 2004;3(2):109-16. https://doi.org/10.1023/B:FAME.0000039863.89137.f9.
16. Baghianimoghadam, M. H., Ardakani, M. F., Akhoundi, M., Mortazavizadeh, M. R., Fallahzadeh, M. H., \& Baghianimoghadam, B. (2012). Effect of education on knowledge, attitude and behavioral intention in family relative with colorectal cancer patients based on theory of planned behavior. Asian Pacific Journal of Cancer Prevention, 13(12), 5995-5998,doi: https:// doi.org/10.7314/APJCP.2012.13.12.5995

17. Bastani R, Glenn BA, Maxwell AE, Ganz PA, Mojica CM, Alber S, et al. Randomized trial to increase colorectal cancer screening in an ethnically diverse sample of first-degree relatives. Cancer. 2015;121(17):2951-9. https://doi.org/10.1002/cncr.29403.

18. Bauer A, Riemann JF, Seufferlein T, Reinshagen M, Hollerbach S, Haug U, et al. Invitation to screening colonoscopy in the population at familial risk for colorectal cancer. Deutsches Aerzteblatt Online. 2018. https://doi.org/ 10.3238/arztebl.2018.0715.

19. Brain K, Sivell S, Bennert K, Howell L, France L, Jordan S, et al. An exploratory comparison of genetic counselling protocols for HNPCC predictive testing. Clin Genet. 2005;68(3):255-61. https://doi.org/10.1111/j.13990004.2005.00491.x

20. Burton-Chase AM, Hovick SR, Peterson SK, Marani SK, Vernon SW, Amos $\mathrm{Cl}$, et al. Changes in screening behaviors and attitudes toward screening from pre-test genetic counseling to post-disclosure in Lynch syndrome families. Clin Genet. 2013;83(3):215-20. https://doi.org/10.1111/cge 12091.

21. Claes E, Denayer L, Evers-Kiebooms G, Boogaerts A, Philippe K, Tejpar S, et al. Predictive testing for hereditary nonpolyposis colorectal cancer: subjective perception regarding colorectal and endometrial cancer, distress, and health-related behavior at one year post-test. Genet Test. 2005;9(1):54-65. https://doi.org/10.1089/gte.2005.9.54.

22. Codori AM, Waldeck T, Petersen GM, Miglioretti D, Trimbath JD, Tillery MA. Genetic counseling outcomes: perceived risk and distress after counseling for hereditary colorectal cancer. J Genet Couns. 2005;14(2):119-32. https://doi.org/10.1007/s10897-005-4062-2.

23. Codori AM, Zawacki KL, Petersen GM, Miglioretti DL, Bacon JA, Trimbath $J$ D, et al. Genetic testing for hereditary colorectal cancer in children: long-term psychological effects. Am J Med Genet A. 2003;116(2):117-28. https://doi.org/10.1002/ajmg.a.10926.

24. Collins VR, Meiser B, Ukoumunne OC, Gaff C, John DJS, Halliday JL. The impact of predictive genetic testing for hereditary nonpolyposis colorectal cancer: three years after testing. Genetics in Medicine. 2007;9(5):290-7. https://doi.org/10.1097/GIM.0b013e31804b45db.

25. Collins V, Halliday J, Warren R, Williamson R. Assessment of education and counselling offered by a familial colorectal cancer clinic. Clin Genet. 2000;57(1):48-55. https://doi.org/10.1034/j.1399-0004.2000.570107.x.

26. Collins V, Halliday J, Warren R, Williamson R. Cancer worries, risk perceptions and associations with interest in DNA testing and clinic satisfaction in a familial colorectal cancer clinic. Clin Genet. 2000;58(6):460-8. https:// doi.org/10.1034/j.1399-0004.2000.580606.x.

27. Collins V, Meiser B, Gaff C, St John DJB, Halliday J. Screening and preventive behaviors one year after predictive genetic testing for hereditary nonpolyposis colorectal carcinoma. Cancer. 2005;104(2):273-81. https:// doi.org/10.1002/cncr.21183.

28. Dudok deWit, A. C., Duivenvoorden, H. J., Passchier, J., Niermeijer, M. F., \& Tibben, A. Course of distress experienced by persons at risk for an autosomal dominant inheritable disorder participating in a predictive testing program: an explorative study. Psychosom Med. 1998;60(5):543-9.

29. Esplen MJ, Harrington S, Leung YW, Aronson M, Rothenmund $H$, Semotiuk K, et al. Telephone versus in-person colorectal cancer risk and screening intervention for first-degree relatives: A randomized controlled trial. Cancer. 2019;125(13):2272-82 https://doi.org/10.1002/cncr.32032.

30. Glanz K, Steffen AD, Taglialatela LA. Effects of colon cancer risk counseling for first-degree relatives. Cancer Epidemiol Biomark Prev. 2007;16(7):1485-91. https://doi.org/10.1158/1055-9965.EPI-06-0914.

31. Gritz ER, Peterson SK, Vernon SW, Marani SK, Baile WF, Watts BG, et al. Psychological impact of genetic testing for hereditary nonpolyposis colorectal cancer. J Clin Oncol. 2005;23(9):1902-10. https://doi.org/10. 1200/JCO.2005.07.102.

32. Gritz ER, Vernon SW, Peterson SK, Baile WF, Marani SK, Amos Cl, et al. Distress in the cancer patient and its association with genetic testing and counseling for hereditary non-polyposis colon cancer. Cancer Res Ther Control. 1999;8:35-49. 
33. Hadley DW, Ashida S, Jenkins JF, Calzone KA, Kirsch IR, Koehly LM. Colonoscopy use following mutation detection in Lynch syndrome: exploring a role for cancer screening in adaptation. Clin Genet. 2011;79(4):321-8. https://doi.org/10.1111/j.1399-0004.2010.01622.x.

34. Hadley DW, Jenkins JF, Dimond E, de Carvalho M, Kirsch I, Palmer CG. Colon cancer screening practices after genetic counseling and testing for hereditary nonpolyposis colorectal cancer. J Clin Oncol. 2004;22(1):39-44. https:// doi.org/10.1200/JCO.2004.06.128.

35. Hadley DW, Jenkins JF, Steinberg SM, Liewehr D, Moller S, Martin JC, et al. Perceptions of cancer risks and predictors of colon and endometrial cancer screening in women undergoing genetic testing for Lynch syndrome. J Clin Oncol. 2008;26(6):948-54. https://doi.org/10.1200/JCO.2007.13.0575.

36. Halbert CH, Lynch H, Lynch J, Main D, Kucharski S, Rustgi AK, et al. Colon cancer screening practices following genetic testing for hereditary nonpolyposis colon cancer (HNPCC) mutations. Arch Intern Med. 2004;164(17):1881-7. https://doi.org/10.1001/archinte.164.17.1881.

37. Hasenbring MI, Kreddig N, Deges G, Epplen JT, Kunstmann E, Stemmler S, et al. Psychological impact of genetic counseling for hereditary nonpolyposis colorectal cancer: the role of cancer history, gender, age, and psychological distress. Genetic testing and molecular biomarkers. 2011;15(4):219-25. https://doi.org/10.1089/gtmb.2010.0165.

38. Hawkes AL, Patrao TA, Green A, Aitken JF. CanPrevent: a telephone-delivered intervention to reduce multiple behavioural risk factors for colorectal cancer. BMC Cancer. 2012;12(1):1. https://doi.org/10.1186/1471-2407-12-560.

39. Ho SMY, Ho JWC, Pau BKY, Hui BPH, Wong RSM, Chu ATW. Hope-based intervention for individuals susceptible to colorectal cancer: a pilot study. Familial Cancer. 2012;11(4):545-51. https://doi.org/10.1007/s10689-012-9545-3.

40. Ingrand I, Defossez G, Richer JP, Tougeron D, Palierne N, Letard JC, et al. Colonoscopy uptake for high-risk individuals with a family history of colorectal neoplasia: A multicenter, randomized trial of tailored counseling versus standard information. Medicine. 2016;95(33):e4303. https://doi.org/10.1097/ MD.0000000000004303.

41. Johnson KA, Trimbath JD, Petersen GM, Griffin CA, Giardiello FM. Impact of genetic counseling and testing on colorectal Cancer screening behavior. Genet Test. 2002;6(4):303-6 https://doi.org/10.1089/10906570260471831.

42. Keller M, Jost R, Haunstetter CM, Kienle P, Knaebel HP, Gebert J, et al. Comprehensive genetic counseling for families at risk for HNPCC: impact on distress and perceptions. Genet Test. 2002;6(4):291-302. https://doi.org/10. 1089/10906570260471822.

43. Keller M, Jost R, Haunstetter CM, Sattel H, Schroeter C, Bertsch U, et al. Psychosocial outcome following genetic risk counselling for familial colorectal cancer. A comparison of affected patients and family members. Clin Genet. 2008;74(5):414-24. https://doi.org/10.1111/j.1399-0004.2008.01089.x.

44. Kinney AY, Boonyasiriwat W, Walters ST, Pappas LM, Stroup AM, Schwartz $M D$, et al. Telehealth personalized cancer risk communication to motivate colonoscopy in relatives of patients with colorectal cancer: the family CARE randomized controlled trial. J Clin Oncol. 2014;32(7):654-62. https://doi.org/ 10.1200/JCO.2013.51.6765.

45. Loader S, Shields C, Rowley PT. Impact of genetic counseling and DNA testing on individuals with colorectal cancer with a positive family history: a population-based study. Genet Test. 2005;9(4):313-9. https://doi.org/10. 1089/gte.2005.9.313.

46. Lowery JT, Horick N, Kinney AY, Finkelstein DM, Garrett K, Haile RW, et al. A randomized trial to increase colonoscopy screening in members of high-risk families in the colorectal cancer family registry and cancer genetics network. Cancer Epidemiol Biomark Prev. 2014;23(4):601-10. https://doi.org/10. 1158/1055-9965.EPI-13-1085.

47. Lynch HT, Lemon SJ, Karr B, Franklin B, Lynch JF, Watson P, et al. Etiology, natural history, management and molecular genetics of hereditary nonpolyposis colorectal cancer (Lynch syndromes): genetic counseling implications. Cancer Epidemiol Biomark Prev. 1997;6(12):987-91.

48. Manne SL, Coups EJ, Markowitz A, Meropol NJ, Haller D, Jacobsen PB, et al. A randomized trial of generic versus tailored interventions to increase colorectal cancer screening among intermediate risk siblings. Ann Behav Med. 2009;37(2):207-17. https://doi.org/10.1007/s12160-009-9103-X.

49. Manne SL, Meropol NJ, Weinberg DS, Vig H, Catts ZAK, Manning C, et al. Facilitating informed decisions regarding microsatellite instability testing among high-risk individuals diagnosed with colorectal cancer. J Clin Oncol. 2010;28(8):1366-72. https://doi.org/10.1200/JCO.2009.25.0399.

50. McClish D, Carcaise-Edinboro P, Esinhart H, Wilson DB, Bean MK. Differences in response to a dietary intervention between the general population and first-degree relatives of colorectal cancer patients. J Nutr Educ Behav. 2014;46(5):376-83. https://doi.org/10.1016/j.jneb.2014.02.015.

51. McGowan EL, Prapavessis H, Campbell N, Gray C, Elkayam J. The effect of a multifaceted efficacy intervention on exercise behavior in relatives of colon cancer patients. Int J Behav Med. 2012;19(4):550-62. https://doi.org/10. 1007/s12529-011-9191-4.

52. Meiser B, Collins V, Warren R, Gaff C, St John DJB, Young MA, et al. Psychological impact of genetic testing for hereditary non-polyposis colorectal cancer. Clin Genet. 2004;66(6):502-11. https://doi.org/10.1111/j.1399-0004. 2004.00339.x.

53. Murakami Y, Okamura H, Sugano K, Yoshida T, Kazuma K, Akechi T, et al. Psychologic distress after disclosure of genetic test results regarding hereditary nonpolyposis colorectal carcinoma. Cancer. 2004;101(2):395-403. https:// doi.org/10.1002/cncr.20363.

54. Pieterse AH, Ausems MG, Van Dulmen AM, Beemer FA, Bensing JM. Initial cancer genetic counseling consultation: change in counselees cognitions and anxiety, and association with addressing their needs and preferences. Am J Med Genet A. 2005;137(1):27-35. https://doi.org/10.1002/ajmg.a. 30839.

55. Rawl SM, Champion VL, Scott LL, Zhou H, Monahan P, Ding Y, et al. A randomized trial of two print interventions to increase colon cancer screening among first-degree relatives. Patient Educ Couns. 2008;71(2):215-27. https:// doi.org/10.1016/j.pec.2008.01.013.

56. Rawl SM, Christy SM, Monahan PO, Ding Y, Krier C, Champion VL, et al. Tailored telephone counseling increases colorectal cancer screening. Health Educ Res. 2015. https://doi.org/10.1093/her/cyv021.

57. Rimes KA, Salkovskis PM, Jones L, Lucassen AM. Applying a cognitive behavioral model of health anxiety in a cancer genetics service. Health Psychol. 2006;25(2):171. https://doi.org/10.1037/0278-6133.25.2.171.

58. Salimzadeh H, Khabiri R, Khazaee-pool M, Salimzadeh S, Delavari A. Motivational interviewing and screening colonoscopy in high-risk individuals. A randomized controlled trial. Patient Educ Couns. 2018;101(6):1082-7 https:// doi.org/10.1016/j.pec.2018.01.015.

59. Shiloh S, Koehly L, Jenkins J, Martin J, Hadley D. Monitoring coping style moderates emotional reactions to genetic testing for hereditary nonpolyposis colorectal cancer: a longitudinal study. Psycho-Oncology. 2008;17(8):746-55. https://doi.org/10.1002/pon.1338.

60. Stephens JH, Moore JWE. Can targeted intervention in CRC patients' relatives influence screening behaviour? A pilot study. Color Dis. 2008;10(2):179-86. https://doi.org/10.1111/j.1463-1318.2007.01258.x.

61. Voorwinden JS, Jaspers JP. Prognostic factors for distress after genetic testing for hereditary cancer. J Genet Couns. 2015:1-9. https://doi.org/10.1007/ s10897-015-9894-9.

62. Wakefield CE, Meiser B, Homewood J, Ward R, O'Donnell S, Kirk J. Randomized trial of a decision aid for individuals considering genetic testing for hereditary nonpolyposis colorectal cancer risk. Cancer. 2008;113(5):956-65. https://doi.org/10.1002/cncr.23681.

63. Resta R, Biesecker BB, Bennett RL, Blum S, Estabrooks Hahn S, Strecker MN, Williams JL. A new definition of genetic counseling: National Society of genetic counselors' task force report. J Genet Couns. 2006;15(2):77-83 10.1007/s10897-005-9014-3.

64. Brédart A, Kop J-L, De Pauw A, Caron O, Fajac A, Noguès C, et al. Effect on perceived control and psychological distress of genetic knowledge in women with breast cancer receiving a BRCA1/2 test result. Breast. 2017;31:121-7 https://doi.org/10.1016/j.breast.2016.10.024.

65. Dryden, W. (2003). Rational emotive behaviour therapy: theoretical developments. Hove ; New York: Brunner-Routledge.

66. Li Z, Li Y, Guo L, Li M, Yang K. Effectiveness of acceptance and commitment therapy for mental illness in cancer patients: A systematic review and metaanalysis of randomized controlled trials. Int J Clin Pract. 2021. https://doi.org/ 10.1111/ijcp.13982.

67. Mikolasek M, Berg J, Witt CM, Barth J. Effectiveness of mindfulness- and relaxation-based eHealth interventions for patients with medical conditions: a systematic review and synthesis. International Journal of Behavioral Medicine. 2017;25(1):1-16 https://doi.org/10.1007/s12529-017-9679-7.

\section{Publisher's Note}

Springer Nature remains neutral with regard to jurisdictional claims in published maps and institutional affiliations. 